\title{
Saving Capitalism - For the Many, Not the Few
} Robert Reich

(Icon, 2016)

\author{
Review by Enda Murphy \\ Department of Business, Dublin Business School \\ Dublin, Ireland
}

(c) Enda Murphy. This work is licensed under the Creative Commons AttributionNonCommercial-ShareAlike 4.0 International License. To view a copy of this license, visit https://creativecommons.org/licenses/by-nc-sa/4.0/ .

As we mark the tenth anniversary of the Global Financial Crisis, we would do well to reflect on its deeper undercurrents and their implications. This book by Prof. Robert Reich of Berkeley, a former Labour Secretary in the Clinton administration, is a valuable and thought-provoking aid in so doing.

The author's Democratic credentials tip his hand as to his economic ideological leanings, but that does not detract from one's enjoyment of his work. As befits his senior academic status, this is a well-reasoned and cogently argued book. It amounts to an appeal for "the ninety percent" of Americans to find their collective voice and power, and to wrest back control of capitalism from its present oligarchic state as Reich sees it.

Reich's opening thrust is to suggest that in viewing the Crisis through the lens of the traditional debate between "The Free Market" and "Government Intervention", we are missing a key point - namely, that Government must set the rules by which the Market operates. In recent decades, he argues, political power has become concentrated in the hands of the rich and powerful few [the "corporate and financial elite"]. As a result, the "rules of the game" have been changed in their favour, to the detriment of the many.

Abundant evidence is presented to back up this assertion. The progressive skew whereby the income of top executives far outstrips that of other workers. The ability of large corporates to keep wage increases well beneath increases in productivity and profits. Bankruptcy laws which allow business owners to walk away from debts with relative ease, in contrast to the crippling student debt in the USA, from which there is no such escape. Extended patent protection for multinationals, which allows "supernormal profits" for lengthy periods. All in all, argues Reich, there has been a major redistribution of wealth in America. Blaming this on Globalisation [jobs going abroad to cheaper locations] and Automation [machines replacing people] is wide of the mark. 
If such be the problem, then the solution lies in harnessing a "countervailing power" [a term coined by JK Galbraith], whereby the middle and lower classes collectively muster the political power to "reclaim" capitalism on behalf of the many. This grouping includes small and medium companies, middle and lower classes, and ethnic minorities - all of whom, according to Reich, have effectively been disenfranchised. The author offers no inkling as to how or when this might happen. If such an alliance were to come into effect, what should they do in order to restore the balance? Reich has a full agenda for them. Get big money out of politics via limits on campaign contributions and increased disclosure requirements. Significantly curtail the "revolving doors" syndrome, whereby Wall Street executives routinely occupy senior White House positions before returning whence they came. Oblige Academics to disclose funding by outside interests, so that we can tell the difference between a genuine opinion and a "bought" one. Impose tougher Antitrust measures, to engender greater competition to the ultimate benefit of consumers. Re-introduce the GlassSteagall requirement to ringfence Retail banking and so confine losses in the "casino" of Investment banking to that domain [ironically it was Clinton who, on the advice of Wall Street insiders, repealed Glass-Steagall!]. Outlaw unfair employment contract terms and increase the minimum wage. An interesting suggestion is to make the corporate tax rate a function of the ratio between the wages of the CEO and those of the median worker. Finally, adoption of the Stakeholder approach [more common in Europe], as opposed to the more narrow Shareholder approach which views the firm as accountable primarily to Shareholders [and thus in thrall to the profit motive].

So far so Socialist, one might say. However, Reich does display a playful sense of irony. He floats an old idea, to pay a minimum income to everyone over the age of eighteen [employed or not]. Before the Free Marketeers decry this from the pulpit, Reich reminds them that it was the 1979 brainchild of F.A. Hayek, champion of laissez faire! He also posits a future where robots do the work but people reap the benefits this time citing none other than Keynes from 1928!

"Saving Capitalism" is a thoughtful work, heart on sleeve by the author. For anyone wishing to understand the contrary view, DBS library carries "The Real Crash", by Peter Schiff, published at the same time. 